\title{
The Carnegie Public Library Movement in North Carolina
}

\author{
Ralph Lee Scott
}

Andrew Carnegie provided more than $\$ 333,000,000$ from the income of his steel empire for what he called "the improvement of mankind." Some $\$ 40,000,000$ of this amount was for the construction of 1,679 public library buildings in 1,412 communities in the United States. North Carolina was the thirty-fifth lowest out of forty-six states in the total dollar amount of construction. New York was the largest with $\$ 6,449,200$, while Nevada received the smallest dollar amount of $\$ 15,000$. North Carolina collected $\$ 166,445$ from the Carnegie Corporation of New York for the erection of public library buildings in the state. When one looks at the per capita expenditure, however, North Carolina comes out the sixth highest among the forty states. The "Old North State" received 52 cents per person for public library construction. This compares with the high of $\$ 1.14$ for Wyoming and 3 cents for Virginia, the low. The number of communities asking for grants ranged from 155 in Indiana to one in Maryland and Nevada. Nine North Carolina communities requested public library funds for the construction of ten buildings from the Carnegie Corporation. The bulk of the communities (633) receiving grants were located in the Midwest. Northwestern United States communities received 252 grants, while the far West received 180, the Northeast 173, the Southeast 112, and the Southwest 61. What happened to the Carnegie legacy in North Carolina? Do these ten buildings still exist? To what use are these buildings put? Did the Carnegie Corporation grants create and foster a viable public library movement in North Carolina? As we shall see the Carnegie library grants were a mixed "triumph and tragedy" in the state of North Carolina. ${ }^{1}$

The first Carnegie public library building constructed in North Carolina was built in 1903 in Charlotte, at a cost of $\$ 25,000$. Funds for the Charlotte Carnegie Public Library were granted by the Carnegie Corporation on March 12, 1901. An additional annex, costing $\$ 15,000$ was added in 1914 making the total Carnegie appropriation to Charlotte $\$ 40,000$. The building was remodeled around 1940 , and served as a public library up until April of 1954. The old Carnegie building was torn down in 1954/55 and the present Public Library of Charlotte and Mecklenburg County building constructed on the same site. The new building opened to the public in November of $1956 .{ }^{2}$

Greensboro received the next Carnegie grant in April of 1902. Records at the North Carolina State Library indicate that the building was built in 1906 at a cost of $\$ 30,000$. The Greensboro Public Library moved out of the Carnegie 
building in 1939, it was later demolished, and is now the site of the West Market Street Methodist Church. This second Carnegie library built in North Carolina was constructed to serve the needs of Greenboro's White population. Another facility was built later to provide a public library for the Black population of the city. ${ }^{3}$

The third Carnegie grant in North Carolina was to the city of WinstonSalem in February of 1903 . The $\$ 15,000$ public library building opened in 1906 . It is currently used as the Our Lady of Fatima Catholic Church. The WinstonSalem Carnegie library building was featured in the April 1981 issue of American Libraries. ${ }^{4}$

Rutherford College, N. C. (near Morganton) received a grant on February 21,1907 of $\$ 2,500$ to construct a public library building for the town. The building, the completion date of which is unknown, was demolished in the 1950s and the site now serves as the location for a Baptist Church. The old Carnegie building "had a turret on the roof," according to Mary Houk, a former resident of Rutherford College, who now works at the Brevard College Library..$^{5}$

In May of 1911, Hendersonville, N. C. received a grant of $\$ 10,000$ for the building of a public library. A new Carnegie library opened in the town in September of 1914. After almost seventy years of service the building is still in use today. It serves now as the home of the Hendersonville Chamber of Commerce. ${ }^{6}$

On April 13, 1914, the town of Andrews, N. C. received a grant of $\$ 5,000$ to construct a public library building. The date of construction of the building is unknown. Soon after opening "officials" at the library asked the Carnegie Corporation in New York for help in obtaining books and for information of how to "record them" and how to "arouse interest in them!" The Andrews Carnegie Library was the latest original Carnegie library building to be demolished in the state of North Carolina. The old building was torn down in 1979 to make way for the present Andrew Carnegie Library. ${ }^{7}$

After what seemed like a long lapse of time, Blacks in Greensboro raised enough funds by city, county, and private subscription to construct a public library facility for their use. An original Carnegie grant of $\$ 10,000$ had been made in 1905 and again in 1915. There was considerable controversy at that time over the site and the Carnegie Corporation cancelled the offerof funds in 1921. After many petitions for renewal from Blacks in Greensboro, the grant was again renewed after it had been withdrawn by the Corporation. The original $\$ 10,000$ gift had to be supplemented by $\$ 4,575$ from the "Negro Board of Education," $\$ 250$ from the city of Greensboro, and $\$ 250$ fromprivate gifts. The Black public library in Greensboro opened in 1924. The building is still in use, currently housing the Office of Special Services and the Office of Freshman Studies of Bennett College. ${ }^{8}$

Negotiations were started with the Carnegie Corporation in 1917 for a public library building in Durham, N. C. A grant was awarded on September 14, 1917, and the building opened to the public on July 6, 1921. Carnegie funds paid 


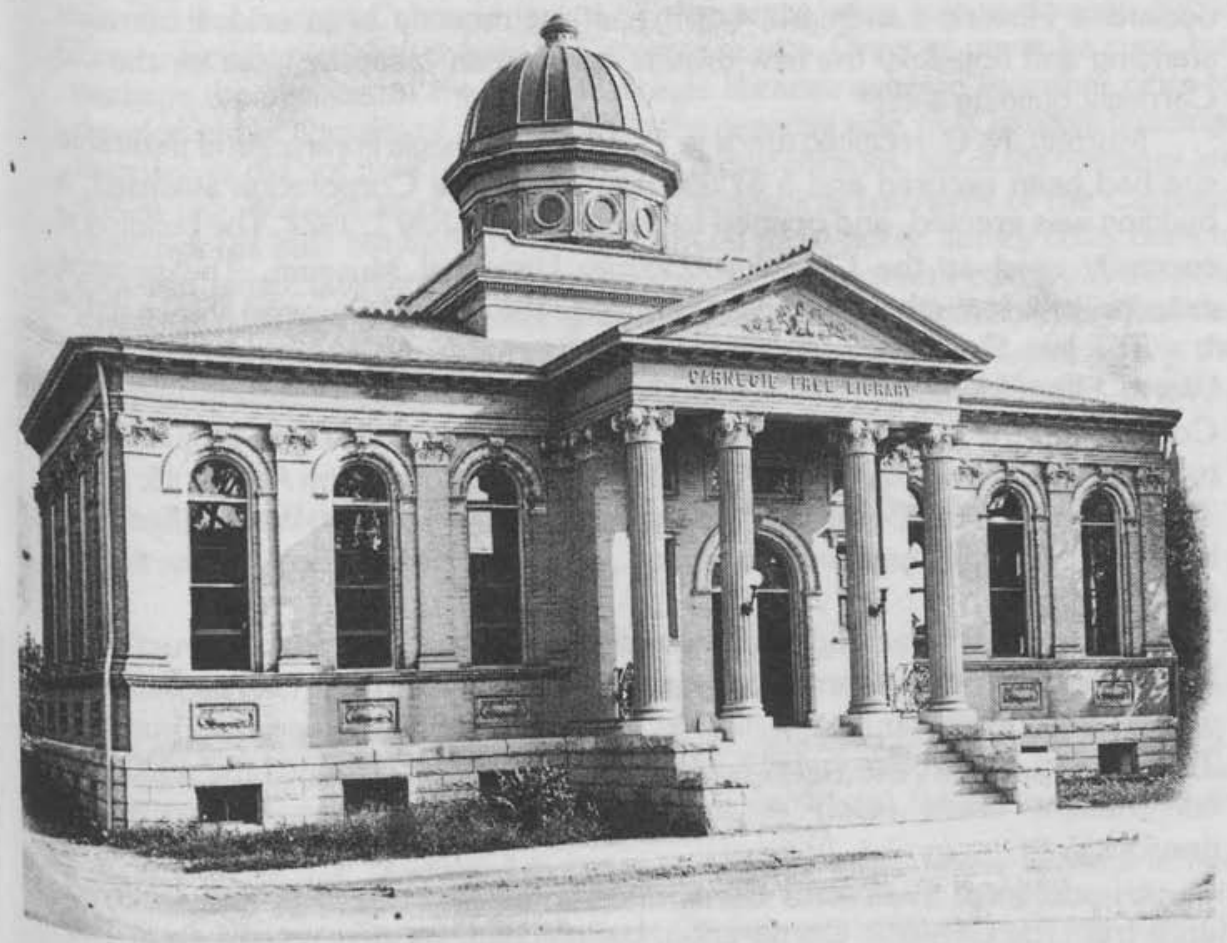

Carnegie Library, Charlotte, built in 1903; razedin 1954/55 to provide site for current building.

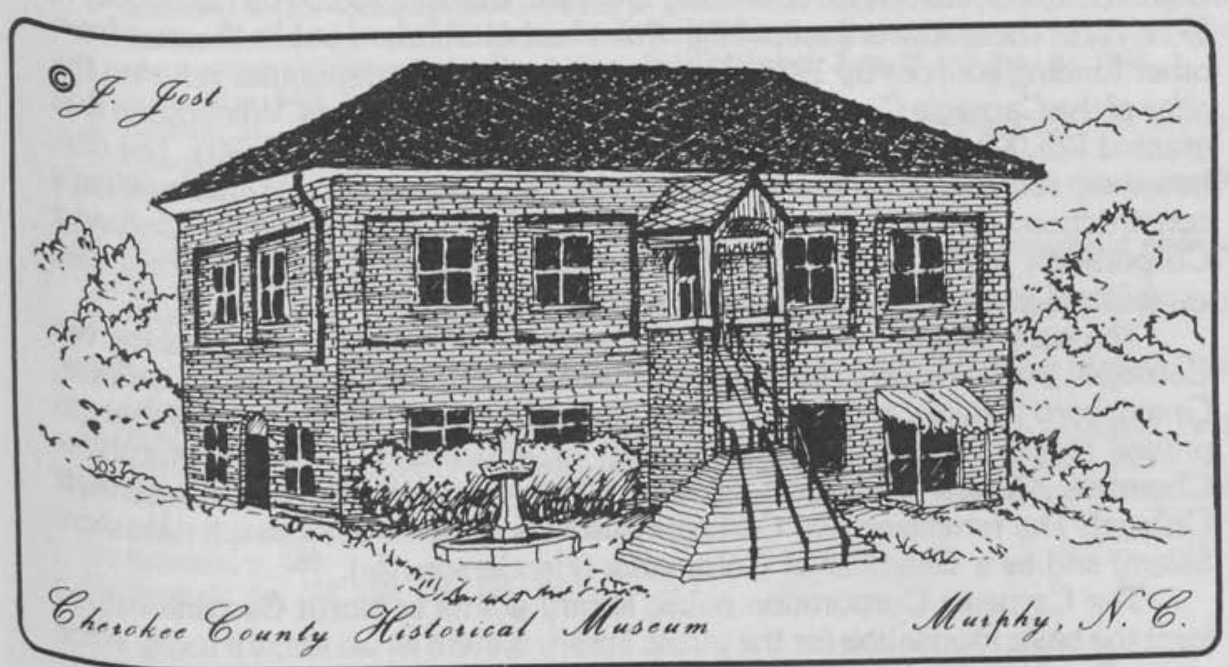

The Murphy Carnegie Library built in 1922 is currently the Cherokee County Historical Museum. 
for $\$ 32,000$ out of the $\$ 45,000$ total cost. The Durham Carnegie library has been declard a Historic Landmark, but it has just recently been sold. It remains standing and hopefully the new owners can find an "adaptive" use for the old Carnegie building shell. ${ }^{9}$

Murphy, N. C. received funds in 1916 for a Carnegie library. After a suitable site had been secured and a $\$ 7,500$ grant from the Corporation awarded, a building was erected, and opened to the public on July 1, 1922. The building is currently used as the Cherokee County Historical Museum. The present exterior retains much the same look today as the original Carnegie library did. ${ }^{10}$

The last Carnegie public library constructed in North Carolina was the Worth Elliot Memorial Library in Hickory. After some dickering with the Corporation the grant of May 3, 1917 was raised from $\$ 11,000$ to $\$ 13,000$. The total cost of the building was $\$ 17,000$. It opened to the public on August 15,1922 . The lot on which the Carnegie library stands was given by Mrs. Worth Elliot. The building is currently used by Inform, Inc., an advertising/public relations firm in Hickory. ${ }^{11}$

This brought to an end over three decades of public library construction in North Carolina by the Carnegie Corporation of New York. All new applications were refused following a resolution to that effect by the Carnegie Corporation Trustees on November 7, 1917. Money continued to flow into the 1920s for construction offers (such as the Greensboro facility for Blacks) made previously. ${ }^{12}$

An additional five North Carolina communities requested and received funds from the Carnegie Corporation, but no buildings were constructed. The exact cause of the failure to build is unknown in four out of five cases. Statesville received $\$ 5,000$ on December 30, 1904; Goldsboro, $\$ 15,000$ on April 23, 1906; High Point, $\$ 15,000$ on November 27, 1906; and Canton, $\$ 5,000$ on December 7, 1911. All of these towns except High Point had established public libraries from other funding sources by 1923 . The reason for these communities refusing the offer of the Carnegie Corporation is not given in public records. Wilmington was granted $\$ 25,000$ for their Carnegie Public Library on January 13, 1903. The city, however, requested additional funds from the Corporation for the building's construction. The additional funds were not forthcoming from the Carnegie Corporation and it appears the city rejected the offer. A public library was established in the city with funds from other sources. ${ }^{13}$

The early 1980s, then, had already seen the destruction of four of the ten Carnegie public library buildings in North Carolina: Andrews, Charlotte, Greensboro (White), and Rutherford College. Two (Durham and Hickory) are in private hands. Two are still being used as educational facilities (MurphyCherokee County Historical Museum and Greensboro (Black)-Bennett College). The remaining two Carnegie buildings are used as a church (Winston. Salem) and as a Chamber of Commerce (Hendersonville).

The Carnegie Corporation public library grants in North Carolina helped form the basic foundation for the public library system as we know it today in the state. The $\$ 166,445$ the Corporation provided, established ten libraries in nine communities. All of these communities continued to have active public libraries 
serving the needs of the citizens of the area. A number of communities asked for but did not accept Carnegie grants. These areas were able to develop public library facilities without the aid of Carnegie grants. One can never be sure, but perhaps the success of the other Carnegie libraries spurred the other cities to develop public libraries of their own. On the negative side, the Carnegie buildings themselves did not pass the test of time as public libraries. Six of the buildings are still in use, but not as public libraries. The physical restraints of the Carnegie buildings (all built between 1903-1924) forced most public library collections to move to larger quarters by the second half of the twentieth century. While the buildings no longer serve their original purpose, the idea of public library facilities for all citizens that was advanced by Andrew Carnegie still remains. This is the remaining legacy of the Carnegie public library movement in North Carolina.

\section{Ralph Lee Scott is Reference Librarian, Joyner Library, East Carolina University.}

\section{References}

1. George S. Bobinski, Carnegie Libraries. (Chicago, American Library Association, 1969), p. 1; Carnegie Corporation of New York. Carnegie Grants for Library Buildings, 1890-1917, (New York, Carnegie Corp., 1943), p. 7-18; Louis Round Wilson, The Geography of Reading. (Chicago, American Library Association, 1938), p. 172-73.

2. Bobinski, p. 212; "Available Information on Carnegie Public Library Buildings in North Carolina," typed information sheet at North Carolina State Library, Raleigh, (cited hereinafter as: Buildings in NC), lp.; Public Library of Charlotte and Mecklenburg County. Thirty, An annual report after thirty years for the Public Library of Charlotte and Mecklenburg County, (Charlotte, Public Library... 1970), p. 11-12; Telephone conversation with librarian at Charlotte Public Library, June 25, 1981.

3. Bobinski, p. 220; "Buildings in NC"; Ethel S. Arnett, Greensboro, North Carolina, the County Seat of Guilford (Chapel Hill, University of North Carolina Press, 1955), p. 94.99.; Telephone conversation with librarian at Greensboro Public Library, June 25 and July 17, 1981.

4. Bobinski, p. 241; "Buildings in NC."

5. Bobinski, p. 234; "Buildings in NC"; Telephone conversation with Mary Houk at Brevard College Library, June 25, 1981.

6. Bobinski, p. 221; "Buildings in NC"; Telephone conversation with librarian at Hendersonville Public Library, June 25, 1981.

7. Bobinski, pp. 163, 208; "Buildings in NC"; Telephone conversation with librarian at Andrews Carnegie Public Library, June 25, 1981.

8. Bobinski, pp. 81, 220; "Buildings in NC"; Telephone conversation with librarian at Greensboro Public Library, June 25, 1981.

9. Bobinski, p. 216; "Buildings in NC"; Telephone conversation with librarian at Durham Public Library, June 26, 1981.

10. Bobinski, p. 228; "Buildings in NC"; Telephone conversation with librarian at Murphy Public Library and the Director of the Cherokee County Historical Museum, June 28, 1981.

11. Bobinski, p. 221; "Buildings in NC"; Telephone conversation with librarian at Hickory Public Library, June 25, 1981.

12. Bobinski, p. 159 .

13. Bobinski, pp. $118,122,124,195,221$. 


\section{We're At Work to Make Your Work Easier.}

It's your job to acquire new and flexible resources for your researchers. That's also our job.

We're in constant touch with librarians to determine your acquisitions needs. Then, we micropublish materials to best fit those needs:

\section{Newspapers}

More than 100 including The New York Times, Atlanta Constitution, Los Angeles Times, and nine North Carolina dailies.

\section{Periodicals}

Government periodicals, popular periodicals (including Newsweek and Rolling Stone), Daily Labor Report and many more.

Current Research Documents Reports from public and private agencies on Crime, Health Care, Housing, Rehabilitation, Nutrition, Consumer Health, and Energy.

Plus current labor union documents.
Historical Research Collections Archives of such noted people and organizations as Aaron Burr, D.W. Griffith, Edward R. Murrow, and The National Woman's Party. An ongoing program for tracing Genealogy and Local History is also available.

For more information, clip and mail the coupon below. Or call collect 919-775-3451.

\section{MICROFILMING CORPORATION} NYT) OF AMERICA

A New York Times Company 1620 Hawkins Avenue / P.O. Box 10 Sanford, North Carolina 27330

Please send me more information about:

Newspapers

Periodicals

Current Research Documents

Historical Research Collections

Please check area(s) of interest: Black History _ Radical Politics Labor

Religion Notables Women's History

Name Title

Library / Institution

Address

Other: 